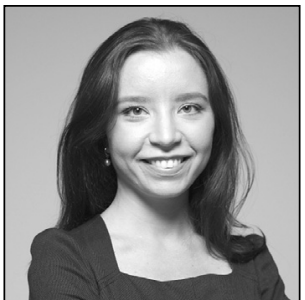

Gea Lepik

Judge, Tallinn Circuit Court MJur (Oxon)

Doctoral student and Junior Lecturer of Civil Law University of Tartu

\title{
Protecting Trade Mark Proprietors Against Unfair Competition in EU Trade Mark Law
}

\section{Introduction}

The importance of modern trade marks has been seen in their economic role of reducing consumer search costs. ${ }^{*}$ In particular, the trade mark enables the consumer to identify the product sought by distinguishing it from other, similar products. ${ }^{{ }^{2}}$ In addition to the origin of the goods, the trade mark provides the consumer with information on their characteristics, ${ }^{*} 3$ enabling him or her to assess the quality of the products offered under the same trade mark. In consequence, trade marks have become a de facto guarantee of a certain quality of the goods or services. This in turn motivates businesses to offer good and uniform quality, ultimately fostering competition on the basis of the quality of goods. ${ }^{*}$ To protect the ability of trade marks to perform this role, they need protection against the use by third parties of similar signs in ways that could create confusion on the part of the consumers. Ensuring such protection has traditionally been the role of trade mark law.

In addition to helping consumers make purchasing decisions, trade marks can be a valuable commercial tool for businesses. They can be used to create an attractive image of the goods or services that they designate, through advertising and marketing. Over time, a trade mark can gain a meaning that, apart from designating the goods or services, conveys certain characteristics and values (e.g. a luxury lifestyle, adventure, or youth). ${ }^{*} 5$ Through this, the trade mark acquires a selling power - i.e. the ability to attract

1 On the role of trade marks in reducing search costs, see WM Landes and RA Posner, 'Trademark Law: An Economic Perspective' (1987) 30 JL \& Econ 265. - DOI: https://doi.org/10.1086/467138.

2 For this reason, Drescher has compared the trade mark to a signal; see TD Drescher, 'The Transformation and Evolution of Trademarks - From Signals to Symbols to Myth' (1992) 82 Trademark Rep 301, 323-324.

3 On the characteristics for which trade marks provide information to the consumer, see A Griffiths, 'Quality in European Trade Mark Law' (2013) 11 Nw J Tech \& Intell Prop 621, 625-627.

$4 \quad$ Landes and Posner (n 1) 269, 270, 280. See also Griffiths (n 3) 631, 635-637.

5 Drescher calls it the myth associated with the trade mark; see Drescher (n 2) 328. On the use of trade marks to communicate information, see also C Davies, 'To Buy or Not To Buy: The Use of a Trade Mark As a Communication Tool Rather Than As a Link between a Product and Its Source - a Further Consideration of the Concept of Dilution' (2013) 35(7) EIPR 373. 
and retain customers. ${ }^{*} 6$ By increasing the value of the designated goods in the eyes of consumers, the trade mark may allow its proprietor to charge a higher price for them. The latter makes the proprietor vulnerable to commercial practices of third parties that either attempt to damage the trade mark's attractive force or take advantage of its status and reputation without putting in the necessary effort and investment. Such practices can harm the trade mark proprietor's business and distort competition, thus constituting unfair competition.

This article shows how EU trade mark law has developed from protecting consumers against confusion to extending the protection to the business value of trade marks and protecting their proprietors against commercial practices that damage or unfairly exploit this value. ${ }^{*} 7$ At the same time, the Court of Justice of the EU (CJEU) has been careful to allow those practices that can be deemed acceptable as part of fair competition. Thereby, EU trade mark law is increasingly becoming an EU law of unfair competition regarding practices involving the use of trade marks. The article is an attempt to explain these developments by looking at the reasons for specific policy choices and decisions of the CJEU, as well as the wider context of EU law dealing with unfair competition. In due course, the reader is given an understanding of how EU law addresses the protection of the commercial value of trade marks.

\section{Prevention of unfair competition as prevailing consideration in shaping the rights of trade mark proprietors in EU trade mark law}

In the EU, the trade mark proprietor's exclusive rights are set out in Art. 10(2) of the Trade Marks Directive $^{* 8}$ (TMD) and Art. 9(2) of the EU Trade Mark Regulation ${ }^{*}$ (EUTMR). These provisions lay down conditions for trade mark infringement that differ on the basis of whether the sign used by the third party and the goods or services for which it is used are identical or similar to those for which the trade mark is protected and whether the trade mark has acquired a reputation. In all cases, the use must be in the course of trade ${ }^{* 10}$ and in relation to goods or services ${ }^{* 11}$. In order to ensure the same protection for trade mark proprietors in all member states, the CJEU has striven to give a uniform interpretation of the 'use' that the proprietor may prohibit. ${ }^{*} 2$ Recent case law has shown a great emphasis on considerations related to unfair competition in shaping the content and scope of the exclusive rights of the trade mark proprietor. These are most prevalent in the so-called functions theory, which has been applied to determine infringement of all trade marks, including the so-called simple marks, and the additional layer of protection granted to trade marks with a reputation. Both cases are examined next.

\subsection{Simple trade marks - the functions theory as a means to protect fair competition}

The legal protection provided for in Art. 10(2)(a) and (b) TMD and Art. 9(2)(a) and (b) EUTMR extends equally to simple and reputed trade marks. Pursuant to Art. 10(2)(a) TMD and Art. 9(2)(a) EUTMR, the proprietor of a registered trade mark is entitled to prevent all third parties not having his consent from

6 According to Schechter, this is the most important function of the trade mark; see FI Schechter, 'The Rational Basis of Trademark Protection' (1927) 40 Harv L Rev 813, 825, 828, 830-831. - DOI: https://doi.org/10.2307/1330367.

7 The author has previously addressed the development of the functions of trade marks in the Estonian legal literature; see G Lepik, 'Kaubamärgi ülesanded ja kaitse Euroopa kaubamärgiõiguses' (2020) 5 Juridica 401.

8 Directive (EU) 2015/2436 of the European Parliament and of the Council of 16 December 2015 to approximate the laws of the Member States relating to trade marks (Text with EEA relevance) [2015] OJ L336/1.

9 Regulation (EU) 2017/1001 of the European Parliament and of the Council of 14 June 2017 on the European Union trade mark (Text with EEA relevance) [2017] OJ L154/1.

10 On this requirement, see Case C-206/01 Arsenal Football Club [2002] ECR I-10273, para 40; Case C-772/18 A (infringement by importing ball bearings) (ECLI:EU:C:2020:341) paras 23-25.

11 An indicative list of such situations is in art 10(3) of the TMD. See joined cases C-236/08 to C-238/08 Google France and Google [2010] ECR I-02417, para 72; Case C-17/06 Céline [2007] I-07041, para 23.

12 TMD, Recital 10; Arsenal Football Club (n 10) paras 44-45. 
using in the course of trade, in relation to goods or services, any sign where the sign is identical to the trade mark and is used in relation to goods or services that are identical to those for which the trade mark is registered (hereinafter 'double identity'). When there is no double identity but the sign used by the third party is at least similar to the trade mark and is used in relation to goods or services that are at least similar to the goods or services for which the trade mark is registered (hereinafter 'double similarity'), the proprietor of the trade mark is entitled to prevent such use pursuant to Art. 10(2)(b) TMD and Art. 9(2)(b) EUTMR if there exists a likelihood of confusion on the part of the public, including the likelihood of association between the sign and the trade mark. The wording of the provisions and recitals suggests that the protection afforded to the trade mark proprietor in the event of double identity is absolute, whereas in the case of double similarity only the trade mark's function of indicating origin is protected, ${ }^{{ }_{13}}$ meaning that the proprietor must prove the existence of a likelihood of confusion on the part of the public. ${ }^{*} 4$ In practice, however, the CJEU has begun to limit the protection afforded under the double identity rule in order to take into account the wider context of competition.

\subsubsection{The trade mark as a guarantor of origin and quality - protecting consumers against confusion}

According to Recital 16 of the TMD and Recital 11 of the EUTMR, the function of the protection afforded by a trade mark is in particular to guarantee the trade mark as an indication of origin. As early as the 1970s, the CJEU clarified that the essential function of the trade mark is to guarantee the identity of the origin of the marked product to the consumer or end-user by enabling him or her, without any possibility of confusion, to distinguish the product or service from others, of another origin. ${ }^{*} 5$ The Court later clarified that for the trade mark to be able to fulfil its essential role in the system of undistorted competition, it must offer a guarantee that all goods or services bearing it have been manufactured or supplied under the control of a single undertaking, which is responsible for their quality. ${ }^{*} 16$ The latter aspect of trade marks has been referred to as their quality function, forming part of the origin function. ${ }^{* 17}$

In the early 2000s, the CJEU began developing the so-called functions theory. It held that the exclusive right under Art. 10(2)(a) TMD is intended to enable the trade mark proprietor to protect his specific interests as proprietor - i.e. to ensure that the trade mark can fulfil its functions. Thus, he can exercise this right only if the third party's use of an identical sign affects or is liable to affect the functions of the trade mark, particularly its essential function of guaranteeing to consumers the origin of the goods. ${ }^{*} 18$ In particular, the interests of the trade mark proprietor are not affected if reference to the trade mark is made for descriptive purposes to reveal the characteristics of a product and not to indicate its origin. ${ }^{* 19}$ On the other hand, there is an adverse effect on this function when consumers are likely to interpret the sign used by the third party as designating the undertaking from which the third party's goods originate and said use creates the impression that these goods come from the trade mark proprietor or an undertaking economically linked to it. ${ }^{{ }^{20}}$ Overall, the criteria used in the assessment largely correspond to those applied under Art. $10(2)(\mathrm{b})$ TMD.

Thus, in EU trade mark law, the origin function of trade marks has always played a central role in justifying the legal protection afforded to trade mark proprietors and in determining its scope. In connection with this essential function, the Court also recognised the quality function of trade marks. Although

13 See TMD, Recital 16; EUTMR, Recital 11. Cf Case C-93/16 Ornua (ECLI:EU:C:2017:571) para 29; Case C-223/15 combit Software (ECLI:EU:C:2016:719) para 27.

14 Case C-292/00 Davidoff [2003] ECR I-00389, para 28; Case C-291/00 LTJ Diffusion [2003] ECR I-02799, paras 48-49; Case C-245/02 Anheuser-Busch [2004] ECR I-10989, para 63.

15 Case 102/77 Hoffman-La Roche $v$ Centrafarm [1978] ECR 01139, para 7.

16 Case C-10/89 CNL-SUCAL $v$ HAG [1990] ECR I-03711, para 13. For later cases, see Case C-299/99 Philips [2002] ECR I-05475, para 30; Arsenal Football Club (n 10) paras 47-48.

17 See Opinion of AG Jacobs in Case C-337/95 Parfums Christian Dior v Evora (ECLI:EU:C:1997:222) para 41; Opinion of AG Mengozzi in Case C-487/07 L'Oréal and Others (ECLI:EU:C:2009:70) para 53.

18 Arsenal Football Club (n 10) paras 51-52.

19 Case C-2/00 Hölterhoff [2002] ECR I-04187, paras 16-17.

20 Anheuser-Busch (n 14) para 60; Case C-48/05 Adam Opel [2007] ECR I-01017, para 24. On application of these criteria in the case of advertising, see Google France (n 11) paras 89-90; Case C-323/09 Interflora and Interflora British Unit [2011] ECR I-08625, para 45. 
the relevant EU instruments did not limit the functions that trade marks could perform, ${ }^{{ }^{2} 21}$ and the CJEU tended to refer to them in the plural, for many years the Court did not mention any other function in assessing the scope of the exclusive rights afforded to trade mark proprietors.

\subsubsection{Recognition of other functions - protecting the business value of trade marks}

As early as the 1990s, it was argued that, in addition to guaranteeing origin and quality, trade marks have other functions, which might be termed communication, investment, or advertising functions and which arise from the investment in the promotion of the mark. While these functions can be seen as derivatives of the origin function, they were regarded as values that deserve protection in their own right. ${ }^{{ }_{22}}$ Eventually, the CJEU too was ready to accept that the approach whereby the trade mark proprietor could prevent the use of his trade mark only if that use undermines its origin function does not take sufficient account of the various roles of trade marks in reality. ${ }^{{ }_{23}}$ In L'Oréal and Others, the CJEU reiterated its earlier view that the proprietor of a trade mark can exercise his exclusive right under what is now Art. 10(2)(a) TMD only if a third party's use of the sign affects or is liable to affect the functions of the trade mark. However, unlike in previous rulings, the Court noted that the functions of a trade mark include, in addition to its main function of guaranteeing to consumers the origin of the goods or services, other functions - in particular, those of guaranteeing the quality of the goods or services in question and of communication, investment, or advertising. ${ }^{*} 24$ This position was soon reiterated in subsequent decisions, including under the EUTMR. ${ }^{* 25}$

As to the advertising function of a trade mark, the CJEU has stated that it is that of using a mark for advertising purposes designed to inform and persuade consumers. Accordingly, the proprietor of a trade mark is entitled to prohibit a third party from using an identical sign without the proprietor's consent, where that use adversely affects the proprietor's use of its mark as a factor in sales promotion or as an instrument of commercial strategy. ${ }^{*} 26$ In practice, however, the CJEU has given a narrow scope to the advertising function. The Court has clarified its nature in the context of the Google 'AdWords' referral service, holding that the use of a sign identical to another person's trade mark in such contexts is not liable to have an adverse effect on the advertising function of the trade mark. ${ }^{* 27}$ Although such use of a sign obliges the proprietor of that mark to intensify its advertising in order to maintain or enhance its profile with consumers, the purpose of the trade mark is not to protect its proprietor against practices inherent to competition. In the Court's view, internet advertising on the basis of keywords corresponding to trade marks constitutes such a practice in that its aim, as a general rule, is merely to offer internet users alternatives to the goods and services of the proprietors of those trade marks. ${ }^{*}{ }^{28}$ Also, it does not deprive the proprietor of the opportunity to use his trade mark effectively to inform and persuade consumers. ${ }^{*} 9$

The trade mark's investment function includes the possibility for the proprietor to employ the trade mark in order to acquire or preserve a reputation capable of attracting potential customers and retaining their loyalty, by means of not only advertising but also various other commercial techniques. ${ }^{*} 30$ This function is adversely affected when the use of an identical sign by a third party, such as a competitor, substantially interferes with the proprietor's use of its trade mark to acquire or preserve such a reputation. When the trade mark already enjoys a reputation, the investment function is adversely affected where the use

21 On the contrary, their recitals referred to the function of the protection afforded to trade marks as 'in particular' to guarantee the trade mark as an indication of origin.

22 Opinion of AG Jacobs in Parfums Christian Dior (n 17) para 42.

23 AG Trestnjak listed 12 functions performed by trade marks in his Opinion in Case C-482/09 Budějovický Budvar (ECLI:EU:C:2011:46); see para 63, note 26.

24 Case C-487/07 L'Oréal and Others [2009] ECR I-05185, para 58.

25 E.g. Google France (n 11) paras 77-79; Interflora (n 20) para 38.

26 Google France (n 11) paras 91-92; Case C-129/17 Mitsubishi Shoji Kaisha and Mitsubishi Caterpillar Forklift Europe (ECLI:EU:C:2018:594) para 37.

27 Google France (n 11) paras 93-94, 98; Case C-558/08 Portakabin [2010] ECR I-06963, paras 32-33.

28 Interflora (n 20) paras 56-58.

29 Ibid [59]; Google France (n 11) paras 96-97.

30 Interflora (n 20) paras 60-63; Mitsubishi Shoji Kaisha (n 26) para 36. 
affects that reputation and thereby jeopardises its maintenance. ${ }^{*}{ }^{31}$ In a similarity to its approach to the advertising function, the CJEU has laid down a strict standard for what constitutes undermining the investment function. Provided that the use of an identical sign by a third party takes place as part of fair competition, it is not sufficient for establishing an adverse effect on the trade mark's investment function that the proprietor is merely obliged to adapt its efforts to acquire or preserve an attractive reputation. For example, internet advertising on the basis of an identical keyword is allowed, provided that the ad neither confuses consumers as to the origin of the goods or services nor adversely affects the trade mark's advertising function. ${ }^{*}{ }^{32}$ It is easier to imagine an adverse effect on the investment function in a situation in which the trade mark has already acquired a good reputation, since in that case the conduct of a competitor may damage that reputation. For example, in the case of luxury goods, the reputation of the trade mark may be damaged if, in the course of advertising, a third party places the trade mark in a context that might seriously detract from the image the trade mark proprietor has succeeded in creating around his trade mark. ${ }^{*} 3$ In some cases, the reputation of a trade mark may be damaged also by the characteristics of the third party using it. The CJEU has further limited reliance on this function by holding that the proprietor of a trade mark cannot rely solely on the fact that the use of an identical sign by a competitor may prompt some consumers to switch from goods or services bearing that trade mark. ${ }^{*}{ }^{34}$ It follows that the damage to the reputation of the trade mark must be likely to affect the behaviour of the average consumer of the relevant goods or services.

The communication function of a trade mark has not been clarified by the CJEU. Recognition of this function is consistent with the fact that a trade mark can convey to consumers information on factors other than the origin of the goods or services that it designates, such as the non-physical characteristics of the product or the company that produced it (e.g. quality, reliability, or luxury). ${ }^{*} 35$ Such information may become part of the brand image as a result of considerable investment by the trade mark proprietor in advertising and promotion. Thus, it is argued, the capacity of the trade mark to act as a communication tool carrying a broader marketing message merits protection in itself. ${ }^{*} 6$ However, without further clarification by the CJEU, it is unclear how to distinguish the protection of this function from the recognition of the quality and investment functions of trade marks, especially if goods' quality is understood to include their intangible characteristics ${ }^{*} 37$.

\subsubsection{The functions theory as a balancing mechanism to protect fair competition}

At first glance, the approach taken by the CJEU in requiring damage to the functions of a trade mark as a condition for infringement under Art. 10(2)(a) TMD seems questionable, as the Directive grants trade mark proprietors protection that is absolute in the event of double identity ${ }^{*}{ }^{3}$. It has been found superfluous to require adverse effects on any function of the trade mark. ${ }^{*} 9$ From that point of view, the Court has restricted the protection of trade marks in the event of double identity. ${ }^{* 40}$ The reason for this may be the desire to consider and balance the competing interests and fundamental rights of all parties, rather than give trade mark proprietors absolute protection. ${ }^{*}{ }^{41}$ The limitations of the trade mark proprietor's exclusive rights under Art. 14 TMD and the EUTMR are narrow and exhaustive and do not provide much space for

31 Ibid.

32 Interflora (n 20) paras 64, 66.

33 Case C-337/95 Parfums Christian Dior v Evora [1997] ECR I-06013, para 47. Cf Interflora Inc v Marks \& Spencer Plc [2013] EWHC 1291 (Ch) [274]. For examples of cases when the context of the sale may damage the reputation of the trade mark, see Opinion of AG Jacobs in Parfums Christian Dior (n 17) para 51; Case C-59/08 Copad [2009] ECR I-03421, paras 57-59.

34 Interflora (n 20) para 64.

35 Opinion of AG Mengozzi in L'Oréal (n 17) para 54.

36 Ibid.

37 See Copad (n 33) paras 24-26; Parfums Christian Dior (n 33) para 45.

38 TMD, Recital 16; EUTMR, Recital 11. See also Interflora (n 20) para 36.

39 E.g. C Morcom, 'Trade Marks and the Internet: Where Are We Now?' (2012) 34(1) EIPR 52.

40 L Bently and others, Intellectual Property Law (5th edn, OUP 2018) 1117. - DOI: https://doi.org/10.1093/he/ 9780198769958.001.0001.

41 Opinion of AG Poiares Maduro in Google France and Google (ECLI:EU:C:2009:569) para 102; Opinion of AG Kokott in Case C-46/10 Viking Gas (ECLI:EU:C:2011:222) paras 59-68. 
weighing different interests. Therefore, the CJEU has begun to balance these interests under the double identity rule, disregarding such adverse effects on the trade mark proprietor's interests as are outweighed by someone else's competing interests. ${ }^{*} 42$ Among other criteria, as can be seen from the examples above, the functions theory has made it possible to take into account, in the infringement analysis, the objective of protecting fair and reasonable competition ${ }^{*} 43$.

At the same time, by accepting additional functions besides the origin function, the CJEU has recognised that a trade mark is not just a symbol providing information about the origin and expected quality of a product or service but also an instrument of commercial strategy used by businesses for various purposes. It is, however, questionable whether it is justified to take these additional functions into account in assessing infringement of simple trade marks. Advertising, investment, and communication functions are performed mostly by trade marks with a reputation, for the protection of which Art. 10(2)(c) TMD and Art. 9(2)(c) EUTMR provide a separate basis. It is argued that recognition of these functions in assessing infringement under the double identity rule leads to the protection of simple trade marks from undermining of functions they do not perform. ${ }^{*} 44$ The prevailing view of academics is that in the case of simple trade marks, only the essential function of indicating origin should be protected. ${ }^{*} 45$ The European Commission proposed clarifying that only the origin function is relevant under the double identity rule, ${ }^{*}{ }^{46}$ but this proposal did not find approval in the proceedings that led to the adoption of the current TMD and EUTMR. Conversely, the CJEU has explicitly held that these other functions are not limited to trade marks with a reputation but can also be performed by a simple trade mark in so far as its proprietor uses it to that end - in particular, for purposes of advertising or investment. ${ }^{*} 4$

Recognition of these other functions may also reflect a desire to protect the proprietors of trade marks that have not yet acquired an attractive reputation from acts or practices of competitors that may impair their ability to use these trade marks for this purpose. Otherwise, the proprietors of simple trade marks would not be adequately protected against acts of unfair competition. For example, if in the event of double identity the proprietor were protected only against adverse effects to the origin function, he would normally not be able to prohibit a third party from using a sign identical to the trade mark for referring not to the third party's own goods or services but to those of the trade mark proprietor (e.g. in comparative advertising). While such uses may negatively affect the commercial interests of the proprietor and distort competition, it is generally not possible to establish an adverse effect on the origin function of the trade mark. ${ }^{*} 48$ The risk of blurring the scope of protection between simple and reputed trade marks is reduced by the fact that, as the examples cited above show, the CJEU has set a high threshold for accepting that a function other than that of indicating origin has been adversely affected. In doing so, the Court appears to have sought a middle ground that would ensure adequate protection of the interests of the trade mark proprietor but also a sufficiently flexible framework for taking into account the legitimate interests of competitors by not prohibiting practices that are part of reasonable competition. It could be argued that the CJEU has shaped the protection of simple trade marks with a view to protecting fair competition.

42 According to Ohly, this was indicated by the approach of the Court in Google France, see A Ohly, 'Keyword Advertising or Why the ECJ's Functional Approach to Trade Mark Infringement Does Not Function' (2010) 41(8) IIC 879, 881. The functions theory has been described as an overarching limitation complementing art 14 TMD; see A Kur, 'Trade Marks Function, Don't They? CJEU Jurisprudence and Unfair Competition Practices' (2014) 45(4) IIC 434, 442-443. - DOI: https://doi. org/10.1007/s40319-014-0200-4.

43 Cf Kur (n 42) 442-443.

44 E.g. M Senftleben, ‘Trade Mark Protection - a Black Hole in the Intellectual Property Galaxy?' (2011) 42(4) IIC 383, 385.

45 Max Planck Institute for Intellectual Property and Competition Law, Study on the Overall Functioning of the European Trade Mark System (Munich, 15.2.2011) 103, para 2.184. Cf M Senftleben, 'Function Theory and International Exhaustion Why It Is Wise To Confine the Double Identity Rule to Cases Affecting the Origin Function' (2014) 36(8) EIPR 518. - DOI: https://doi.org/10.2139/ssrn.2356772; Ohly (n 42) 881. Cf Kur (n 42) 438.

46 Commission, 'Proposal for a Directive of the European Parliament and of the Council to approximate the laws of the Member States relating to trade marks (recast)' COM (2013) 0162 final, 7.

47 Interflora (n 20) paras 39-40.

48 Study on the Overall Functioning of the European Trade Mark System (n 45) 103, para 2.180. 


\subsection{Trade marks with a reputation - protection against unfair dilution}

For trade marks with a reputation, Art. 10(2)(c) TMD provides extended protection relative to that of simple trade marks. Under this provision, the proprietor of a trade mark that has a reputation in the Member State is entitled to prevent third parties from using in the course of trade, in relation to goods or services, signs identical to, or similar to, the trade mark, irrespective of whether these are used in relation to goods or services identical to, similar to, or not similar to those for which the trade mark is registered, where use of the sign without due cause takes unfair advantage of, or is detrimental to, the distinctive character or the repute of the trade mark. ${ }^{*} 49$ Thus, while the scope of protection of a trade mark is generally limited to the goods or services in respect of which it is registered, marks with a reputation are also protected against the use of similar signs in relation to dissimilar goods or services. The CJEU has stated that infringements of the exclusive rights conferred on the proprietors of trade marks with a reputation are a consequence of a certain degree of similarity between the mark and the sign, by virtue of which the relevant section of the public makes a connection between the sign and the mark - i.e. establishes a link between them without confusing them. ${ }^{* 0}$ The extended protection applies where said sign is used without due cause in a way resulting in at least one of the three types of harm to the trade mark.

The protection against detriment to the distinctive character, also referred to as 'dilution', 'whittling away', or 'blurring', is intended to protect the mark's ability to identify the goods or services for which it is registered and used as coming from the proprietor of that mark. This is done by prohibiting the use of similar signs by third parties where that use could lead to 'dispersion of the identity and hold upon the public mind' of the trade mark and thus undermine its ability to raise immediate association with the goods or services for which it is registered. ${ }^{*}{ }^{1}$ It has been accepted that the more unique the mark and the stronger its reputation, the greater the threat to its distinctive character. ${ }^{*}{ }^{52}$ This protects famous trade marks from becoming commonplace or a generic name for certain goods or services. ${ }^{*} 3$ Detriment to the repute of the mark, also referred to as 'tarnishment' or 'degradation', is caused when the goods or services for which the identical or similar sign is used by the third party may be perceived by the public in such a way that the trade mark's power of attraction is reduced when, for example, they possess a characteristic or quality that is liable to have a negative impact on the image of the mark. ${ }^{*} 4$ This should include situations wherein the goods offered by the third party are of poor or uneven quality, as well as cases in which the trade mark proprietor's own goods are advertised or sold in a context seriously detracting from the prestigious image and aura of luxury that the proprietor has succeeded in creating around his trade mark ${ }^{*} 55$. The concept of 'taking unfair advantage of the distinctive character or the repute of the trade mark', also referred to as 'parasitism' or 'free-riding', is related to the advantage taken by the third party when, in consequence of the use of an identical or similar sign, the image of the mark or the characteristics it projects are transferred to the goods identified by this sign. This approach protects the proprietor of a trade mark with a reputation against third parties seeking to 'ride on the coat-tails' of that mark in order to benefit from its power of attraction, its reputation and prestige, and to exploit the marketing effort expended by its proprietor in order to create and maintain the image of that mark. ${ }^{*}{ }^{6} 6$

The scope of application of this ground for infringement has been extended over time. Under the earlier Directives 89/104/EEC and 2008/95/EC, granting extended protection to trade marks with a reputation was left optional for the member states. ${ }^{*} 7$ The current TMD makes it mandatory to ensure such protection. Furthermore, when the wording of Art. 5(2) of the earlier directives, as well as Regulation 207/2009, on EU trade marks, limited the application of the ground of dilution to cases where a sign identical or similar to the trade mark has been used in relation to dissimilar goods or services, the CJEU extended its application to

\footnotetext{
See also EUTMR, art 9(2)(c).

L'Oréal (n 24) para 36; Case C-408/01 Adidas-Salomon and Adidas Benelux [2003] ECR I-12537, paras 29, 31.

Case C-252/07 Intel Corporation [2008] ECR I-08823, para 29; L'Oréal (n 24) para 39.

Intel (n 51) paras 69, 74; Case C-375/97 General Motors [1999] ECR I-05421, para 30.

Opinion of AG Jääskinen in Interflora and Interflora British Unit (ECLI:EU:C:2011:173) paras 80-83.

L'Oréal (n 24) para 40.

Parfums Christian Dior (n 33) paras 45-47. For examples, see note 33.

L'Oréal (n 24) paras 41, 48-49.

Art 5(1) and (2). This was confirmed by the CJEU in Case C-48/05 Adam Opel [2007] ECR I-01017, para 33.
} 
cover also cases wherein the mark is used in relation to identical or similar goods or services ${ }^{*}{ }^{8}$. Since 2015 , this position has been codified in Art. 10(2)(c) TMD and Art. 9(2)(c) EUTMR.

The additional protection afforded to the proprietors of trade marks with a reputation, alongside the gradual increase of its relevance in EU trade mark law, can be explained by the wish to ensure protection against unfair competition in the EU. From the perspective of trade mark law, the justification of such an extension of the protection against dilution is questionable, since the extended protection afforded to reputed trade marks has traditionally been seen as intended for cases in which the proprietor cannot rely on the likelihood of confusion as a ground for infringement. ${ }^{*} 5$ However, it must be accepted that when a trade mark with a reputation is used in relation to identical or similar goods or services, this use may also cause damage to its distinctive character (e.g. through it becoming a generic name) or repute (e.g. degrading comparative advertising) or may unfairly exploit its distinctive character or repute (e.g. use of a keyword in a referral service to promote imitations). The aim in protecting trade marks with a reputation against blurring, tarnishment, and free-riding is to protect the efforts and investment of the proprietor in creating a trade mark with a positive image and independent economic value (goodwill). ${ }^{* 60}$ Damaging or taking unfair advantage of these attributes can be regarded as constituting dishonest commercial practices. Therefor, from the perspective of ensuring undistorted and fair competition, it is justified to protect the proprietor of a trade mark with a reputation equally in cases involving use in relation to identical, similar, or dissimilar goods or services.

Despite extending its scope of application, the CJEU has interpreted the infringement ground of dilution in a way that takes into account the interests of third parties, the actual adverse effects on the trade mark proprietor, and thus the fairness of the third party's act in its specific circumstances. For example, in Interflora the CJEU stated that not every use of a trade mark with a reputation by a third party in relation to identical goods contributes to turning that mark into a generic term. For example, this is not the case when the selection of an identical or similar sign as a keyword in an internet referencing service merely serves to draw attention to the existence of an alternative product or service, provided that the advertisement triggered by the use of this keyword enables the reasonably well-informed and reasonably observant internet user to tell that the goods or services offered originate not from the proprietor of the trade mark but from a competitor. ${ }^{*} 61$ To make the establishment of dilution even more burdensome, the CJEU has required the proprietor to show that the use of an identical or similar sign has had an impact on the market by way of an actual or likely change of the average customer's behaviour. ${ }^{* 62}$ The need to assess the use of an identical or similar sign in the context of competition is evident in the case of comparative advertising. It is generally accepted that comparative advertising can stimulate competition between suppliers of goods and services to the consumer's advantage. ${ }^{*} 63$ Thus, it is not surprising that the CJEU has found that the use of a trade mark with a reputation in comparative advertising that satisfies the conditions laid down in Art. 4 of the MCAD does not constitute violation of the proprietor's rights even if the advertiser benefits from the force of the trade mark in attracting the attention of the public to the advertising, as such use and any advantage gained through it are consistent with fair competition. ${ }^{* 64}$

An important limitation to relying on the protection afforded by Art. 10(2)(c) TMD is the requirement that, for this protection, the use of the sign be without 'due cause'. This concept is intended to strike a balance between the exclusive rights of the trade mark proprietor and the interests of third parties, ${ }^{*} 65$ and it has been used in practice to enable third parties to pursue practices that are within the limits of normal competition. For example, the CJEU has acknowledged that where a competitor of the proprietor of a trade mark with a reputation selects that trade mark as a keyword in an internet referencing service, the purpose of that use is to take advantage of the distinctive character and repute of the trade mark. ${ }^{*}{ }^{6}$ However, the

58 Case C-292/00 Davidoff [2003] ECR I-00389.

59 JT McCarthy, 'Proving a Trademark Has Been Diluted: Theories or Facts?' (2004) 41 Hous L Rev 713, 730-732; cf art 16(3) of the Agreement on Trade-Related Aspects of Intellectual Property Rights (15 April 1994), Marrakesh Agreement Establishing the World Trade Organization, Annex 1C, 1869 UNTS 299 (TRIPS Agreement).

60 Cf Opinion of AG Jääskinen in Interflora (n 53) para 50.

61 Interflora (n 20) paras 79-81.

62 Intel (n 51) para 77. See also Interflora (n 20) para 83.

63 Recital 6 of Directive 2006/114/EC of the European Parliament and of the Council of 12 December 2006 concerning misleading and comparative advertising (Codified version) (Text with EEA relevance) [2006] OJ L376/21 (MCAD).

64 L'Oréal (n 24) paras 72, 79; Case C-533/06 O2 Holdings ET O2 (UK) [2008] ECR I-04231, para 45.

65 Case C-65/12 Leidseplein Beheer and de Vries (ECLI:EU:C:2014:49) para 46.

66 Interflora (n 20) paras 85-87. 
Court has considered that where the advertisement displayed on the basis of said keyword puts forward an alternative to the goods or services of the proprietor of the trade mark without offering a mere imitation, without causing dilution or tarnishment, and without adversely affecting the functions of the trade mark at issue, such use falls, as a rule, within the ambit of fair competition so is not without 'due cause.." ${ }^{\prime} 7$ The intention of the third party has been considered relevant in assessing whether a use has a 'due cause'. For example, the proprietor of a trade mark with a reputation may be obliged to tolerate the use of a similar sign if that sign was in use before the trade mark application was filed and is being used in good faith. ${ }^{*}{ }^{6}$

\section{The recent developments in context - should EU trade mark law take the role of EU unfair competition law of trade marks?}

The need to ensure effective protection against unfair competition in EU member states arises from Art. 1obis of the Paris Convention, ${ }^{*} 69$ reiterated in Art. 2 of the TRIPS Agreement. The Paris Convention's Art. 1obis(2) defines an act of unfair competition as any act of competition contrary to honest practices in industrial or commercial matters, while paragraph 3 includes a list of practices that, in particular, should be prohibited. Their common aspect has been seen as lying in 'the attempt (by an entrepreneur) to succeed in competition without relying on his own achievements in terms of quality and price of his products and services, but rather by taking undue advantage of the work of another or by influencing consumer demand with false or misleading statements. ${ }^{*}{ }^{* 0}$ Although only such uses by unauthorised third parties of signs identical or similar to trade mark as create confusion between competitors should directly fall under Art. 1obis(3) (1), ${ }^{*}$ paragraph 3 does not set out an exhaustive list of dishonest practices. ${ }^{*} 72$ The Model Provisions against Unfair Competition ${ }^{*} 73$, prepared by WIPO for its implementation, also include a rule prohibiting any act or practice that damages, or is likely to damage, the goodwill or reputation of another's enterprise, inclusive of damage or likely damage resulting from dilution of the goodwill or reputation attached to a trade mark, regardless of whether said act or practice causes confusion. ${ }^{*} 4$ Several national systems too extend the protection connected with unfair competition to cover dilution, denigrating another trader, and free-riding on another's efforts or reputation. ${ }^{*} 75$

Art. 1obis of the Paris Convention does not require the enactment of specific legislation to fight unfair competition but enables its form and content to reflect the different traditions and approaches of national systems. ${ }^{*} 76$ In the EU, protection against unfair competition is fragmented. There are directives on specific aspects of unfair competition, such as prohibiting unfair commercial practices directed toward consumers (e.g. the Unfair Commercial Practices Directive ${ }^{*} 77$, UCPD), regulating advertising (the MCAD), and

67 Ibid [89]-[91]; Google France (n 11) paras 102-103.

68 Leidseplein Beheer and de Vries (n 65) paras 55-56, 60.

69 Paris Convention for the Protection of Industrial Property, as last revised at the Stockholm Revision Conference (20 March 1883) 828 UNTS 305.

70 'Protection against Unfair Competition - Analysis of the Present World Situation' (1994) WIPO publication 725(E) 24, para 31.

71 Pursuant to art 10bis(3)(i), the prohibited practices include 'all acts of such a nature as to create confusion by any means whatever with the establishment, the goods, or the industrial or commercial activities, of a competitor'.

72 On acts not expressly mentioned in art 10bis, see 'Protection against Unfair Competition' (n 70) paras 48-68.

73 (1996) WIPO publication 832(E).

74 The Model Provisions, art 3(1) and (2)(i).

75 'Protection against Unfair Competition' (n 70) paras 48, 54-60.

76 See M Höpperger and M Senftleben, 'Protection against Unfair Competition at the International Level - the Paris Convention, the 1996 Model Provisions and the Current Work of the World Intellectual Property Organisation', in RM Hilty and F Henning-Bodewig (eds), Law against Unfair Competition: Towards a New Paradigm in Europe? (Springer-Verlag Berlin Heidelberg 2007) 61, 63. - DOI: https://doi.org/10.1007/978-3-540-71882-6_3.

77 Directive 2005/29/EC of the European Parliament and of the Council of 11 May 2005 concerning unfair business-to-consumer commercial practices in the internal market and amending Council Directive 84/450/EEC, Directives 97/7/EC, 98/27/ EC and 2002/65/EC of the European Parliament and of the Council and Regulation (EC) No 2006/2004 of the European Parliament and of the Council ('Unfair Commercial Practices Directive') (Text with EEA relevance) [2005] OJ L149/22. 
ensuring the protection of trade secrets ${ }^{*} 78$. Even now, there is no general instrument regulating commercial practices that, although not directly harming consumers, may hurt competitors and business customers. ${ }^{*} 79$ Accordingly, the member states have been able to follow different routes. For example, in Estonia, the Restriction of Unfair Competition and Protection of Business Secrets Act ${ }^{* 80}$ (RUCPBSA) provides a general prohibition of unfair competition and a list of three examples, including disclosure of misleading information and disparagement of a competitor or its product or service. ${ }^{* 81}$ Germany adopted its new Act against Unfair Competition ${ }^{* 82}$ (UWG) in 2004, replacing the UWG 1909. The UWG contains a general provision for prohibiting unfair commercial practices and provides examples of such practices. It offers specific rules on certain types of practices and regulates the legal consequences of violation of the Act. ${ }^{*} 83$ In France, claims arising from acts of unfair competition can be brought under the general provisions of the Civil Code on civil liability. ${ }^{*} 84$ In contrast, the UK, which until only recently was also an EU Member State, ${ }^{*} 85$ does not recognise a general tort of unfair competition. Instead, it has been considered compliant with Art. 10bis of the Paris Convention by virtue of a combination of legal mechanisms, including consumer protection legislation, the common law torts of passing off and malicious falsehood, and the equitable claim for breach of confidence. $^{* 86}$

These examples show that the measures taken in European countries to implement Art. 10bis of the Paris Convention and the level of specificity of the regulation differ considerably, thus potentially also leading to differences in outcome between similar cases. Therefore, the first merit of taking into account considerations connected with the fairness and honesty of the relevant business practices when applying EU trade mark law is its effect of harmonising the EU unfair competition law with regard to acts and practices involving the use of trade marks. As indicated above, such acts as result in deception of consumers or damage to the trade mark proprietor as a result of harm to reputation or of dilution of goodwill are an important category of dishonest practices that Art. 10bis of the Paris Convention is designed to fight. A uniform EU-level approach to these practices is desirable as, unlike many other types of unfair business practices, the conditions for the use of trade marks have a direct impact on the internal market as they affect the cross-border circulation of goods and provision of services. As the law of trade marks is already harmonised in the EU, it is reasonable to attempt to achieve the relevant goals of unfair competition law in the same framework, instead of a possible parallel system. Furthermore, as the CJEU has held that the TMD effects complete harmonisation of the rules related to the rights conferred by a trade mark, ${ }^{*} 8$ it is questionable whether it would even comply with EU law if national courts were to extend or, worse, limit the exclusive rights conferred by a trade mark by reference to national unfair competition law. ${ }^{*} 88$

As mentioned above, two types of unfair practices that directly involve the use of trade marks are regulated on the EU level by the MCAD and UCPD, the first prohibiting misleading advertising and the second

78 Directive (EU) 2016/943 of the European Parliament and of the Council of 8 June 2016 on the protection of undisclosed know-how and business information (trade secrets) against their unlawful acquisition, use and disclosure (Text with EEA relevance) [2016] OJ L157/1.

79 Recital 8 of the UCPD calls on the Commission to carefully examine the need for Community action in the field of unfair competition beyond the remit of this Directive and, if necessary, make a legislative proposal to cover these other aspects of unfair competition. Thus far, no such proposal has been made.

80 RT I, 07.12.2018, 2.

81 RUCPBSA, §3(2)1).

82 Gesetz gegen den unlauteren Wettbewerb in the version published on 3 March 2010 (BGBl. IS 254), which was last amended by art 1 of the law of 26 November 2020 (BGBl. IS 2568).

83 For an overview of the UWG as adopted in 2004, see D W, 'A New Act against Unfair Competition in Germany' (2005) 36(4) IIC, 421; M Finger and S Schmeider, 'The New Law against Unfair Competition: An Assessment' (2005) 6 German LJ 201. DOI: https://doi.org/10.1017/s2071832200013572. Note that the UWG has been amended since its adoption.

84 Arts 1240 and 1241 of the new provisions of the Code Civil created by Ordonnance n ${ }^{\circ} 2016-131$ of 10 February 2016.

85 Although the UK withdrew from the EU on 31 January 2020, its laws related to the protection of trade marks are still in line with EU law. Because of its differences in legal tradition from continental Europe, as well as extensive case law on trade marks, the UK is a useful reference country for trade mark matters in Europe.

86 R Arnold, 'English Unfair Competition Law' (2013) 44 IIC 63, 65. - DOI: https://doi.org/10.1007/s40319-012-0010-5; Bently (n 40) 926.

87 E.g. Case C-661/11 Martin Y Paz Diffusion (ECLI:EU:C:2013:577) para 54.

88 In Martin Y Paz Diffusion, the CJEU held that limiting the rights of the trade mark proprietor was allowed only on the grounds arising from the TMD; ibid [55]. For criticism of this approach, see Kur (n 42) 448-453. 
prohibiting unfair commercial practices directed toward consumers. Taking into account the definition of 'misleading advertising' in Art. 2(b) MCAD and the features to be taken into account in the assessment, ${ }^{*} 89$ the Directive prohibits, inter alia, confusing use by third parties of a sign identical or similar to a trade mark in advertising. The MCAD also establishes requirements for comparative advertising, requiring it not to, inter alia, discredit or denigrate, create confusion with, or take advantage of the reputation of a competitor's trade mark. ${ }^{*} 90$ The UCPD prohibits practices that deceive or are likely to deceive the average consumer in relation to, inter alia, the commercial origin of the goods or the rights of the trader, such as ownership of IP rights, along with certain confusing practices involving the marketing of a product. ${ }^{*}{ }^{* 1} \mathrm{How}-$ ever, trade mark proprietors often benefit little from these instruments in practice. First, the thresholds for the conditions for violation of the rules contained therein are relatively high. For example, violation of the requirements of the UCPD presupposes that the average consumer is influenced or likely to be influenced to enter into a transaction that he or she would not otherwise have. ${ }^{*} 92$ More importantly, however, neither the MCAD nor the UCPD contains an efficient enforcement regime for safeguarding the interests of trade mark proprietors. Art. 11(1) UCPD and Art. 5(1) and (2) MCAD permit the member states to opt for administrative enforcement to ensure compliance with the requirements of these directives and do not require them to confer a private right of action on persons having a legitimate interest in ensuring compliance with their provisions, including competitors. Thus, the directives have retained different national systems in the field of enforcement. ${ }^{*} 93 \mathrm{~A}$ choice in favour of administrative enforcement was made in the UK ${ }^{*} 94$ and has been made also in, for instance, Estonia ${ }^{*} 95$. It has been argued that there is no private right of action on grounds of violation of the provisions transposing the MCAD and UCPD in the UK. ${ }^{*} 96$ Such grounds may exist under the Estonian law of delict pursuant to \$1043 and \$1045(1)7) and (3) of the Law of Obligations Act ${ }^{*} 97$ if at least one of the purposes of the rules implementing the relevant provisions of the EU directives in the Advertising Act or the Consumer Protection Act is to protect competitors against damage arising from such acts. ${ }^{*} 98$ On the basis of the articles setting out the objectives for those directives and the recitals, it is clear that, while this may be the case for the MCAD, which is aimed at protecting traders against misleading advertising and distortion of competition, the purpose of the UCPD is to protect consumers. ${ }^{*}{ }^{99}$ Even among those the member states where taking private legal action for enforcing the requirements of the MCAD and UCPD is possible, the legal remedies available and the conditions for their use may differ. For example, under the German UWG, which, inter alia, transposes the directives, ${ }^{*}{ }^{* 100}$ the injured party is entitled to sue for ceasing of an illegal commercial practice and claim compensation for damage, but said rights are limited to direct competitors. ${ }^{*} 101$

Accordingly, the second aspect of value in handling cases of unfair business practices involving the use of trade marks under the law of trade marks is a solid mechanism of private enforcement established in the EU for IP rights infringements. In particular, the treatment of such practices as trade mark infringements

89 Including any information that the advertisement contains on the commercial origin of the goods or the rights of the advertiser, such as IP rights; see MCAD, art 3(a) and (c).

90 MCAD, art 4(a), (d), (f), and (h).

91 UCPD, art 6(1)(b), (f), and (2)(a).

92 Ibid. See also art 5(1) and (2) of the UCPD. According to Recital 11 of the UCPD, the Directive prohibits those unfair commercial practices that distort consumers' economic behaviour.

93 See C Handig, 'The Unfair Commercial Practices Directive - A Milestone in the European Unfair Competition Law?' (2005) 16 Eur Bus L Rev 1117, 1131.

94 Arnold (n 86) 68. See regulations 13, 15, and 18 of the Business Protection from Misleading Marketing Regulations 2008 (SI 2008/1276); regulations 19 and 26 of the Consumer Protection from Unfair Trading Regulations 2008 (SI 2008/1277).

95 See: $\S 30$ of the Advertising Act (RT I 2008, 15, 108; RT I, 01.07.2020, 13); §61 and $\S 64$ of the Consumer Protection Act (RT I, 31.12.2015, 1; RT I, 04.01.2021, 14).

96 Arnold (n 86) 69-71.

97 RT I 2001, 81, 487; RT I, 04.01.2021, 19.

98 Such a condition for claiming compensation for damages resulting from a violation of an obligation arising from the law has been reiterated in the case law of the Supreme Court. See, e.g. judgments of the Civil Chamber of 17.12.2012, 3-2-1-161-12, para 11; 06.06.2018, 2-16-14655/24, para 14.1.

$99 \mathrm{MCAD}$, art 1 and recitals 3, 4, and 9; UCPD, art 1 and recitals 6, 8, 11, and 23. Cf Arnold (n 86) 69, arguing that the directives protect the public in general, not a limited class of persons.

100 UWG, fn 1.

101 UWG, s 8(1) and (3)1); s 9; s 2(1)3). 
invokes the availability of remedies and procedures provided for in Directive 2004/48/EC ${ }^{* 102}$ (the IPRED). While the member states are free to extend, for internal purposes, the provisions of the IPRED to include acts involving unfair competition, the binding force of the Directive is limited to infringement of IP rights. ${ }^{*} 103$ Considering the disadvantages of enforcement by public authorities, such as the constraints posed by the resources and priorities of the enforcement authorities, one finds that the possibility of private enforcement is an inexpensive and efficient solution for strengthening the fight against unfair competition. ${ }^{*}{ }^{104}$ It also ensures compensation for traders who have been adversely affected by the unfair conduct, helping to minimise its effect on competition.

\section{Conclusions}

To protect trade mark proprietors against commercial practices of third parties that could hinder the use of the trade mark in informing and attracting customers, negatively affect its selling power, or exploit its attractive force, the EU legislator and the CJEU have broadened the protection afforded under trade mark law to cover such acts. At the same time, the CJEU has searched for the right balance between the exclusive rights of trade mark proprietors and the interests of third parties, attempting to maintain the conditions of normal competition. As a result, EU trade mark law is increasingly becoming the EU law of unfair competition with regard to practices involving the use of trade marks. In light of the lack of harmonisation of unfair competition law in the EU, at least pertaining to practices that affect businesses, this approach helps to ensure the necessary degree of harmonisation while avoiding a parallel system of protection. Compared to existing EU instruments of unfair competition law, which also prohibit certain uses of trade marks, the widening of the scope of protection afforded under trade mark law provides trade mark proprietors with an efficient mechanism for enforcing their rights. All in all, the developments discussed in this article can be welcomed both from the perspective of trade mark proprietors and from that of other market participants.

102 Directive 2004/48/EC of the European Parliament and of the Council of 29 April 2004 on the enforcement of intellectual property rights (Text with EEA relevance) [2004] OJ L157/45.

103 IPRED, art 3 and recital 13.

104 It has proven successful under the German UWG; see W (n 83) 431-432. 